\title{
Revitalization of the Technical and Vocational Education (TVE) Programmes for Youth Empowerment in Nigeria
}

\author{
Jacinta Ifeoma Obidile ${ }^{1}$, Helen Efeyadu Uzoekwe ${ }^{2}$ \\ ${ }^{1}$ Department of Technology and Vocational Education, Nnamdi Azikiwe University, Awka, Nigeria \\ ${ }^{2}$ Department of Guidance and Counseling, Nnamdi Azikiwe University, Awka, Nigeria
}

Email address:

ij.obidile@unizik.edu.ng (J. I. Obidile), helyunizik@yahoo.com (H. E. Uzoekwe)

\section{To cite this article:}

Jacinta Ifeoma Obidile, Helen Efeyadu Uzoekwe. Revitalization of the Technical and Vocational Education (TVE) Programmes for Youth Empowerment in Nigeria. International Journal of Vocational Education and Training Research. Vol. 4, No. 1, 2018, pp. 45-47. doi: 10.11648/j.ijvetr.20180401.17

Received: July 10, 2018; Accepted: July 25, 2018; Published: August 28, 2018

\begin{abstract}
Most Nigerian youths are faced with several problems such as unemployment, poverty, hunger and starvation in spite of the abundant natural and human resources in Nigeria. These unwholesome effects could be minimized when the youths are meaningfully engaged. One of the ways of engaging the youth meaningfully to minimize these unwanted situations is to ensure job creation through Technical and Vocational Education (TVE). Technical and Vocational Education (TVE) which is the form of education that is meant to prepare its recipients for employment and become economically independent, should be used to impart skill acquisition to the youths to minimize the rate of unemployment of the youths in Nigeria. Developing youths with skills would definitely improve production output, occupational diversity and standard of living. This study therefore examines the role of the TVE in relation to youth empowerment and proffers strategies for revitalization of the TVE programmes to enhance youth engagement in order to reduce unemployment, poverty, hunger and starvation of the youths in Nigeria.
\end{abstract}

Keywords: Technical and Vocational Education (TVE), Revitalization, Youth Empowerment, Unemployment, Job Creation and Nigeria

\section{Introduction}

The term 'youth' generally refers to a period of life between childhood and adulthood. Youths are seen as the foundation of any society. The youths remain the core of the economic growth for the future of any nation. [1]defines youths as all young males and females between the ages of 18-35 years who are citizens of the Federal Republic of Nigeria. The estimated population of the youths as at 2016 was $61,306,413$ or $31.7 \%$ of the total population and the total population was projected to be 193,392,517 (National Population Commission in [2]. It is expected that these figures must have increased but, because the youth statistics for the year 2017 and 2018 has not been established as at the time of writing this article, the researchers chose to use the available statistics. The youths obtaining $31.7 \%$ of the population shows that they have large number.

Most of these youths are faced with several problems such as unemployment, poverty, hunger and starvation. With the youths' energy and highly inventive minds; skill acquisition, development and training are important so as to prepare them for work in both formal and informal sectors of the economy. It is therefore pertinent to empower and inculcate into the youths the culture and attitude of hands -on learning through Technical and Vocational Education (TVE) programmes so that they could be meaningfully engaged and empowered to raise their standard of living. Human resource development, through a well planned education and training initiatives such as TVE could contribute significantly to promote the interest of the youths, businesses, economy and the society at large.

Technical and Vocational Education (TVE) is the type of education which equips the learner with the necessary knowledge and specific skills with which to start work [3]. It is believed that with adequate implementation, constant evaluation and revitalization of Technical and Vocational Education (TVE) policies and programmes, the Nigerian youths could benefit and become economically independent. 
Revitalization of the TVE programmes should be in tandem with the needs and aspirations of the people in the community and the local industries so that communities could develop, jobs could be created and youths could be gainfully employed in order to raise the economy of the nation. It is therefore pertinent to harness the potentials of this strong work force (the youth) to boost the nation's economy through TVE programmes.

Youth empowerment means engaging the youth in meaningful social and economic activities that would help the youth gain vital skills, responsibilities and confidence necessary to become productive. According to [4] youth empowerment is a means of encouraging youths to gain the skills and knowledge that will allow them to overcome obstacles in life. [5] stated that youths are empowered when they acknowledge that they have or can create choices in life, are aware of the implications of these choices, make an informed decision freely, take action based on that decision and accept responsibility for the consequences of their action.

Empowering young people means creating and supporting the enabling conditions under which young people can act on their own rather than at the direction of others. Youth empowerment is necessary as it would create an enabling environment that would grow new sets of entrepreneur, enhance private sector investment and contribute to socio-economic advancement. Youth empowerment is therefore a necessary tool which could be used to eradicate unemployment, poverty, hunger and starvation of the workforce populace which could be achieved through revitalization of the TVE programmes. As Franklin D. Roosevelt the $32^{\text {nd }}$ president of United States noted in his address at University of Pennsylvania that "we cannot always build the future for our youths, but we can build our youths for the future."

\section{Aspects of Empowerment to the Youths Through TVE}

Technical and Vocational Education is the education which equips the recipient with the competencies needed to start a life of work. It is expected that TVE would empower its recipients (which are mostly the youth) psychologically, economically and socio-culturally, among others. Psychological empowerment enhances individual consciousness, belief in self-efficacy, awareness and knowledge of the problem and how individual can address the problem that harms their quality of life[6]. This kind of empowerment helps youths to think and identify the inherent talent in them and the strategy that would help them showcase the talent. Economic empowerment helps youths to know how to take ownership of their assets and have income security.

Socio-cultural empowerment helps youths to know about social inclusion and literacy and imbibe the cultural norms which would help them redefine themselves and contribute to social, economic and cultural development. From the a foregoing discussion, it could therefore be said that revitalization of the TVE programmes for youth empowerment means strengthening the VTE programmes so as to equip the youth with innate abilities and skills with which to make a positive change that would contribute to economic, social, political and cultural development. TVE programmes if well re-structured and implemented should play important roles in improving the wellbeing of the youths. Unemployed graduates, school drop outs or indigent youths could receive TVE training as it provides opportunity to learn a skill or trade with which to survive.

Several countries like United States, Japan and United Kingdom have benefited from Technical and Vocational Education as this has brought a lot of economic advancements to their respective countries [7, 8]. In Nigeria, the case is different. Nigeria tends to concentrate on universal primary education and literacy, but do not pay sufficient attention to skill training for the youths. So many TVE policies and programmes have been mapped out for the youth empowerment in Nigeria but due to dwindling economy, lack of adequate entrepreneurial skills, minimal job creation, increase in population growth, lack of adequate marketable and productive skills, weak and ineffective implementation mechanism $[9,10]$, they have little effect. It is important to emphasize here that when these youths are idle, they might be involved in violence (which is often an expression of frustration) or maladaptive behavior such as becoming agents of social destabilization, disunity and economic sabotage. Nonetheless, when the youths are empowered, the beneficial outcomes are improved social skills, improved behavior, increased self-esteem and self-efficacy and economic advancement [11].

\section{Strategies for Revitalization of the Technical and VocationalEducation (TVE) Programmes}

However, all hope is not lost, in order to revitalize the TVE programmes in Nigeria so as to engage the youths meaningfully to achieve economic independence, the following strategies are proposed:

\subsection{Open Apprenticeship Scheme}

The TVE programmes should be extended to include open apprenticeship scheme where youths should be encouraged to register and be attached as apprentices to companies, ministries, parastatals and professional craftsmen and women. Here, five to ten mentors could be chosen from each local government depending on the number of youths in that area. The mentor's workshops could be used as the training ground and knowledge sharing centre for the interested youths. However, the number of mentors could be checked from time to time to know when to increase or decrease their number as there would be new entrants and graduates. Upon graduation, certificates should be given which should be recognized by the public. There should be no fee charge; the mentors should be paid by the government from the Education Trust Fund (ETF). 


\subsection{Incorporation of Waste to Wealth Activities in TVE Programmes}

TVE programmes should incorporate 'waste to wealth' activities. In doing this, a vast area of land would be mapped out for collection and conversion of neglected materials and other scraps into useful products. The area should be managed by the TVE administrators with constant supervision by the Ministry of Environment. Idle youths should be given training on how to gather the waste materials, what to wear or use when gathering the materials, among others. There should be payment options for the youths involved, which could be either by cash or by supplying the youths with the recycled material which they could sell and make their gains to boost their financial capacity.

\subsection{Incorporating Practical Aspects of Agriculture in TVE}

TVE programmes incorporate agriculture in theory but in practice there is little to show for it. With high rate of youth unemployment, there is need that the agricultural sector should be given its rightful place in the TVE programmes using practical approach. Youths who are interested in farming should be encouraged and registered under the TVE programmes. They should be given the opportunity by providing them with relevant training and orientation required to start farming ventures. Improved tools and equipment should be provided to them and constant monitoring should be applied. They should be required to provide quarterly reports in order to ascertain their status at any given time. Help should be given to them when needed so as to achieve their goals. Although mechanized farming is encouraged, but, labour- intensive techniques could also be used from time to time to provide an immediate temporary employment to a large number of the unemployed youths to boost their financial capacity.

\subsection{Maintaining Different Levels in the TVE Programme}

TVE programmes in Nigeria should be operated at different levels, so that at any level a youth stops, he could be given recognition, which could be in the form of a certificate or an award. The award or certificate when presented, could be used to get employment at the public or private establishments or further his career depending on the competencies possessed by the bearer. An examination body such as National Board for Technical Education (NBTE) could be given the responsibility of assessing the acquired skills possessed by the trainee in order to ascertain the issuance or non-issuance of the certificate or the award.

\subsection{Providing Vocational Guidance}

Youths should be provided with vocational guidance in order to enhance their capacity in choosing a career occupation. They should be exposed to several vocational areas from which they could select their area(s) of interest. Efforts should be made to invite resource persons in their chosen area to share their experiences with the youths in order to motivate them.

\section{Conclusion}

No nation could be maximally developed when the youths are idle. Youths should be meaningfully engaged through the TVE. The TVE programmes should be revitalized to engage Nigerian youths irrespective of differences in their capabilities and capacities.It is therefore imperative that demand-driven TVE programmes which must be flexible and respond to the needs of the community and the local industry be established so that youths could choose one or more specialized area(s)and make their living.

\section{References}

[1] National Youth Policy (2009). Document of the Federal Republic of Nigeria.Retrieved from

www.youthpolicy.org/national/Nigeria_2009_National_Youth Policy

[2] Jega, A. M. (2017). Youth and the future of Nigeria. A paper delivered at the 5th Convocation Lecture at Nile University, University Village, Abuja.

[3] Obidile, I. J. (2014). Vocational and Technical Education (VTE) in the $21^{\text {st }}$ Century: The Way Forward. NAU Journal of Technology and Vocational Education (2014), 1(1), 1-6.

[4] Fan, F. A., Agu, P. A. \&Tsav, S. A., (2016). Youth empowerment as a necessary condition for nation building: Nigeria experience. International Journal of Education, Learning and Development 4 (6), 9-18.

[5] Commonwealth Plan of Action for Youth Empowerment (PAYE) 2006-2015. Retrieved from www.youthpolicy.org/library/wpcontent/.../2006_Commonwe alth_PAYE_Eng.

[6] Krauss, S. E., Collura, J., Zeldin, S., Ortega, A., Abdullah, H. \&Sulaiman, A. H. (2013). Youth-Adult Partnership: Exploring Contributions to Empowerment, Agency and Community Connections in Malaysian Youth Programs. Journal of Youth and Adolescence 43 (9), 1550-1562. ISSN 0047-2891. doi:10.1007/s10964-013-0027-1.

[7] Murata, S. \& Stern, S. (1993). Technology Education in Japan. Journal of Technology Education 5(1), 29-37.

[8] Puckett, J., Davidson, J. \& Lee, E. (2012). Vocational Education: The missing link in economic development. Boston consulting group. Retrieved from www.bcg.com

[9] Emeh, I. (2012). Tackling youth unemployment in Nigeria; The Lagos state development and empowerment Programmes Initiatives. Afro Asian Journal of Social Sciences 3 (3.4), 2229-5313.

[10] Okafor E.E. (2011). Youth Unemployment and Implications for Stability of Democracy in Nigeria. Retrieved from http://www.jsdafrica.com/Jsda/V13No1_Spring2011.

[11] Krauss, S. E., Collura, J., Zeldin, S., Ortega, A., Abdullah, H. \&Sulaiman, A. H. (2013). Youth-Adult Partnership: Exploring Contributions to Empowerment, Agency and Community Connections in Malaysian Youth Programs. Journal of Youth and Adolescence 43 (9), 1550-1562. ISSN 0047-2891. doi:10.1007/s10964-013-0027-1. 